\title{
PENGALAMAN ORANGTUA YANG MEMILIKI ANAK DENGAN HIDROSEFALUS
}

\author{
Mawar Oktaviani' ${ }^{1}$, Lina Dewi Anggraini ${ }^{2}$, Chatarina Indriati Kusumaningsih ${ }^{2}$ \\ ${ }^{1}$ Mahasiswa S-1 Keperawatan, STIK Saint Carolus, Jakarta, 10440, Indonesia \\ ${ }^{2}$ Dosen Keperawatan, STIK Saint Carolus, Jakarta, 10440, Indonesia \\ E-mail: mawaroktaviani11@ymail.com, linadewiam@gmail.com, todearindri@gmail.com
}

\begin{abstract}
ABSTRAK
Hidrosefalus adalah salah satu penyakit kongenital pada anak yang menyebabkan gangguan pada fase tumbuh kembang. Anak dengan hidrosefalus tentu membuat orangtua merasa khawatir dan memberikan perhatian lebih. Kekhawatiran ini akan memengaruhi orangtua. Pengobatan dan perawatan yang panjang menambah beban orangtua yang memiliki anak hidrosefalus. Tujuan penelitian: mengeksplorasi pengalaman orangtua yang memiliki anak dengan hidrosefalus di Semarang. Metode: metode kualitatif dengan pendekatan fenomenologi deskriptif, dilakukan mulai tanggal 22 Januari 2016-30 Januari 2016 pada orangtua yang memiliki anak dengan hidrosefalus di Semarang. Cara pengumpulan data dengan teknik wawancara dan alat pengumpulan data dalam penelitian ini ialah peneliti sendiri yang akan dibantu oleh alat perekam wawancara (tape recorder), field note, alat tulis, dan pedoman wawancara. Teknik analisis data menggunakan analisis Colaizzi dan diolah dengan program Nvivo versi 10. Jumlah informan dalam penelitian ini berjumlah 8 orang. Metode triagulasi yang digunakan adalah membandingkan hasil wawancara dengan sumber terkait. Hasil: Hasil penelitian menunjukkan lima tema, yaitu proses berduka, proses perawatan, mekanisme koping orangtua, upaya kesehatan, dan perubahan nilai. Diskusi: Penelitian ini menyarankan untuk dapat meminimalkan masalah orangtua yang memiliki anak dengan hidrosefalus.
\end{abstract}

Kata Kunci: hidrosefalus, pengalaman orangtua.

\begin{abstract}
Hydrocephalus is one of the congenital diseases in children which causes disorder in their phases of growth and development. A child with hydrocephalus certainly makes parents worried and needs more attention. Such worry will affect parents. Long treatment and care increase burden of the parents who have a child with hydrocephalus. Objective: This study is aimed at exploring the experience of parents who have children with hydrocephalus in Semarang. Methods: This study employed a qualitative method with descriptive phenomenology approach. It was conducted from January 22, 2016 until January 30, 2016 on parents who had children with hydrocephalus in Semarang. Date were collected through interview and using instruments, including tape recorder, field notes, stationery and interview guidelines. Date were analyzed Colaizzi's method and processed using NVivo 10. The number of respondens in this study was 8 people. Triangulation method was used to compare the results of interviews with relevant sources. Results: This study generated 5 themes, namely grieving process, treatment process, parents' coping mechanisms, health efforts, and changes in values. Discussion: It is expected thath this study could minimize problems encountered by parents who have children with hydrocephalus.
\end{abstract}

Keywords: hydrocephalus, parent's experience. 


\section{LATAR BELAKANG}

Menurut Departemen Kesehatan Republik Indonesia (2014), anak merupakan anugerah bagi setiap orangtua, merupakan aset bangsa dan generasi penerus yang akan menentukan masa depan bangsa. Setiap orangtua memiliki harapan yang sangat besar dapat memiliki anak yang sehat dan sempurna sehingga dapat dibanggakan dan didambakan untuk melanjutkan keturunannya. Namun, nyatanya banyak penyakit kronis yang dialami anak seperti epilepsi, diabetes, cacat mental, cacat fisik, dan hidrosefalus. Penyakit hidrosefalus yang diderita oleh salah satu anak akan memengaruhi orangtua. Jika anak mulai menunjukkantandadangejalahidrorosefalus, keluarga, khususnya orangtua dituntut untuk dapat mengambil keputusan dengan cepat ke mana akan merawat anggota keluarga yang sakit (Santun dan Agus, 2008).

Istilah hidrosefalus berasal dari kata hidro yang berarti 'air' dan chepalon yang berarti 'kepala'. Menurut World Health Organization (2012) dan Ball (2012), hidrosefalus adalah sebuah kondisi saat terjadi gangguan cairan serebrospinal (CSF) yang diakibatkan reaksi tubuh terhadap keseimbangan produksi dan reabsorbsi sehingga terjadi penumpukan di dalam kepala, menyebabkan tekanan meningkat, dan tulang tengkorak berkembang menjadi lebih besar dari ukuran normal sehingga membutuhkan perawatan dan pengobatan khusus.

Mutaqqin (2011) mengungkapkan bahwa anak-anak dengan hidrosefalus biasanya mengalami penurunan pada pencapaian tumbuh kembang jika dibandingkan dengan perkembangan anak normal seusianya. Hal ini terjadi karena adanya penekanan pada otak akibat gangguan sirkulasi cairan di kepala. Penurunan pencapaian tumbuh kembang ini dapat menyebabkan perubahan secara permanen yang tentunya memengaruhi kualitas hidup anak.
Data statistik dari Hydrocephalus Association (2013) menyebutkan sekitar 1-2 per 1.000 kelahiran bayi di Amerika lahir dengan hidrosefalus. Hal itu tidak jauh berbeda dengan kejadian hidrosefalus di Indonesia yang berkisar antara 0,2-4 setiap 1.000 kelahiran (Maliawan, 2008). Berdasarkan data di RSU dr. Soedarso Pontianak, sepanjang tahun 2008 dan 2009 terdapat kasus hidrosefalus sebanyak 100 anak (Edikta, 2011). Kejadian hidrosefalus juga banyak terjadi di perkotaan. Angka kejadian kasus hidrosefalus di RSUP Fatmawati Jakarta selama 3 bulan dari Januari-Maret 2013 sebanyak 22 anak. Di Semarang terdapat 21 anak lahir dengan hidrosefalus selama tahun 2014-Januari 2016.

Saat dihadapkan pada kondisi anak yang mengalami hidrosefalus, pada umumnya orangtua akan mengalami perasaan takut, khawatir, marah, sedih bercampur syok (Hunt dan Marshall, 1994 dalam Handayani, 2008). Kekhawatiran dan perasaan sedih tersebut dapat terjadi karena ketidakmampuan anak dalam pencapaian fase pertumbuhan dan perkembangan, seperti tidak dapat melakukan kontak sosial yang paling sederhana (Marijani, 2003). Saat orangtua mengharapkan dapat mendengar suara dan celotehan dari anaknya, dapat berkomunikasi dengan anaknya, serta melihat anak sehat seperti anak lain, anak tidak dapat melakukannya. Hal itu dapat membuat orangtua merasa tidak berharga. Perasaan ini juga muncul akibat anak tidak merespons stimulus yang diberikan (Marijani, 2003).

Hasil observasi peneliti menunjukkan orangtua mengalami kecemasan terhadap pertumbuhan dan perkembangan anak. Walaupun mengalami perasaan cemas, orangtua selalu tersenyum dan gembira mengajak anak bermain. Beberapa orangtua bahkan memutuskan tidak bekerja untuk 
fokus merawat anak. Berdasarkan fenomena tersebut, pertanyaan penelitian ini adalah bagaimana pengalaman orangtua yang memiliki anak dengan hidrosefalus?

\section{METODE}

Metode penelitian yang digunakan pada penelitian ini ialah metode penelitian kualitatif dengan analisis pendekatan fenomenologi deskriptif. Jenis penelitian ini dipilih karena peneliti ingin mengeksplorasi pengalaman orangtua yang memiliki anak dengan hidrosefalus. Peneliti menggunakan desain penelitian fenomenologi karena merupakan bentuk investigasi yang sistematis, kritis, dan teliti terhadap sebuah fenomena yang bertujuan untuk mendalami sebuah struktur atau inti sari dari suatu fenomena dalam hidup dan menggambarkan secara akurat pengalaman hidup setiap hari (Rose dkk., 2001 dalam Wasis, 2008).

Teknik pengambilan sampel dalam penelitian ini ialah non-probability sampling, yaitu dengan cara purposive sampling. Purposive sampling adalah dipilih dengan kriteria dan tujuan tertentu sehingga memberikan data yang diperlukan (Susilo dkk., 2015). Kriteria yang dipakai ialah orangtua yang memiliki anak dengan hidrosefalus. Jumlah sampel dalam penelitian ini sebanyak 8 informan.

Proses pengumpulan data berlangsung di Semarang mulai 22 Januari 2016-30 Januari 2016. Penelitian dilakukan di Semarang karena terdapat yayasan yang membantu pengobatan dan perawatan anak-anak dengan hidrosefalus yang membutuhkan bantuan kesehatan dan dukungan. Berdasarkan data yang didapat, ada 75 anak hidrosefalus yang mendapat penanganan sejak tahun 2014-Januari 2016. Cara pengumpulan data dalam penelitian ini ialah dengan wawancara dan catatan lapangan (field note). Wawancara mendalam digunakan untuk menggali pengalaman orangtua yang memiliki anak dengan hidrosefalus. Strategi wawancara dalam penelitian ini ialah dengan pertanyaan terbuka. Alat pengumpulan data ialah peneliti sendiri yang dibantu oleh alat perekam wawancara (tape recorder), field note, alat tulis, dan pedoman wawancara. Sebelum melakukan wawancara kepada informan, peneliti melakukan uji coba wawancara untuk berlatih teknik wawancara mendalam. Pada hasil uji coba wawancara, peneliti menghindari pertanyaan tertutup dan memakai $5 \mathrm{~W}+1 \mathrm{H}$.

Analisis data dalam penelitian ini menggunakan pendekatan metode Colaizzi dengan analisis menggunakan perangkat lunak N-Vivo. Setelah hasil wawancara dianalisis menggunakan metode Colaizzi, untuk meningkatkan kepercayaan hasil data, dilakukan pengabsahan data/validitas (trustworthiness) dan reliabilitas, yaitu usaha untuk meningkatkan derajat kepercayaan data sehingga penelitian ini benar-benar ilmiah dan dapat dipertanggungjawabkan dari segala segi. Validitas dan reliabilitas dapat menjelaskan berbagai teknik operasional yang mendukung ketepatan data yang dihasilkan dari penelitian kualitatif, yaitu kredibilitas, dependabilitas, konfirmabilitas, transferabilitas (Afiyanti, 2008). Uji keabsahan data dapat dilakukan dengan member check, dengan cara informan yang telah diwawancara diminta untuk membaca transkrip yang telah dibuat oleh peneliti. Selanjutnya, validasi data dilakukan dengan triangulasi. Triangulasi adalah teknik pemeriksaan data melalui sumber. Proses triangulasi dalam penelitian ini ialah dengan membandingkan hasil wawancara dengan hasil penelitian yang dilakukan mengenai orangtua yang memiliki anak dengan hidrosefalus serta ditambah dengan sumber teori terkait tema-tema hasil wawancara. 
Selama pengumpulan data, peneliti tergambar dalam skema berikut. menerapkan etika penelitian untuk melindungi hak dan kewajiban informan sebagai sumber informasi yang dibutuhkan untuk penelitian. Prinsip etika dalam metode penelitian kualitatif pada ilmu keperawatan meliputi manfaat (beneficence), menghormati martabat (respectforhuman dignity), keadilan (justice), bentuk persetujuan (informed consent), kerahasiaan (confidentiality), dan malefisiensi(Polit dan Beck, 2012).

Pada penelitian ini, semua etika penelitian sudah diterapkan. Sebelum melakukan wawancara, informan dijelaskan mengenai maksud, tujuan, manfaat, serta kerahasiaan penelitian. Jika informan setuju, dilakukan wawancara. Informan diberikan surat persetujuan bersedia menjadi informan. Tidak ada informan yang menolak untuk dilakukan wawancara. Selama proses wawancara, semua orangtua menangis saat mengungkapkan pengalaman memiliki anak dengan hidrosefalus. Setelah menghentikan sejenak proses wawancara, semua orangtua siap melanjutkan kembali wawancara.

\section{HASIL DAN DISKUSI}

Gambaran karakteristik informan pada penelitian ini ialah orangtua yang memiliki anak dengan hidrosefalus, jumlah informan sebanyak 8 orang dengan rentang usia 1845 tahun dan usia anak mulai dari 18 hari-4 tahun. Anak dalam penelitian ini didiagnosis hidrosefalus saat di dalam kandungan dan setelah kelahiran; di dalam kandungan, anak didiagnosis hidrosefalus saat usia kandungan 8-9 bulan dan saat kelahiran anak didiagnosis hidrosefalus saat usia 3 minggu-3 bulan setelah kelahiran. Anak hidrosefalus dalam keluarga adalah anak bungsu dan anak tunggal.

Berdasarkan tujuan penelitian, diperoleh lima tema yang berkaitan dengan pengalaman orangtua yang memiliki anak dengan hidrosefalus. Tema yang dihasilkan

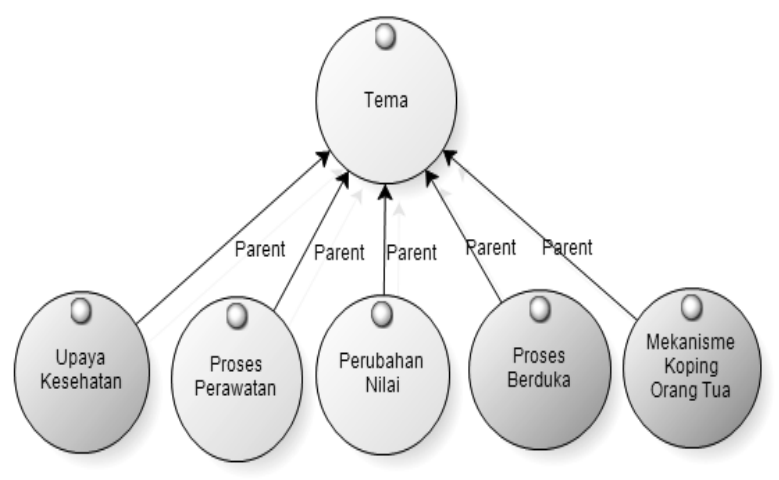

Gambar 1. Tema yang berkaitan dengan orang tua yang memiliki anak dengan hidrosefalus

\section{Proses Berduka}

Saat pertama kali orangtua mendengar anak didiagnosis hidrosefalus, semua orangtua mengalami proses berduka.

“... waktu anak saya divonis ya kecewa banget, kenapa Tuhan kasih anak saya menderita seperti ini? Dosa saya apa? ..." (I1)

“... waktu itu dalam hati saya terus terang sempat marah, sempat mengeluh sama Tuhan, kenapa Tuhan...kenapa Tuhan?" (12)

Pada tema proses berduka ini terdapat lima subtema, yaitu mengingkari, marah, depresi, tawar-menawar dan penerimaan.

Proses berduka merupakan suatu proses psikologis dan emosional yang dapat diekspresikan secara internal maupun eksternal setelah kehilangan (Puri, Laking, dan Treasaden, 2011). Proses berduka memiliki lima tahapan untuk memahami bagaimanaberdukamemengaruhikehidupan seseorang yang dalam hasil pengamatan Kubler Ross (1969 dalam Chapman, 2013) antara denial (mengingkari), anger (marah), bargaining (tawar menawar), depression (depresi) dan acceptance (penerimaan).

Pada penelitian ini, saat pertama kali mendengar anaknya didiagnosis hidrosefalus, semua orangtua mengalami 
proses berduka sesuai dengan pernyataan Kubler Ross. Pada penelitian ditemukan tahapan yang sama, yaitu mengingkari, marah, tawar-menawar, depresi, dan penerimaan. Serupa dengan hasil penelitian yang dilakukan Koesoemo (2010), ditemukan bahwa ketika keluarga mengetahui bahwa salah satu anggota keluarganya mengalami sakit dengan kebutuhan khusus, keluarga mengalami proses berduka yang mendalam, menetap, dan berkepanjangan melalui tahapan penyangkalan, kemarahan, depresi, tawar-menawar, dan penerimaan.

\section{Proses Perawatan}

Tema proses perawatan terdapat 8 subtema yaitu mencari informasi, biaya minim, tindakan medis, tindakan non-medis, memenuhi kebutuhan anak, upaya merawat, perubahan aktivitas dan keluhan fisik.

"Kan butuh biaya untuk operasi gitu Mbak. Kalau operasi sendiri ya gak mampu biayanya mahal, biayanya gak murah." (14)

".... sebisa mungkin saya rawat sebaikbaiknya, saya rawat sebisa mungkin gimana biar tambah sehat, tambah sehat tak rawat dengan kasih sayang" (17)

Proses perawatan keluarga merupakan tugas keluarga dalam melindungi keamanan dan kesehatan seluruh anggota keluarga serta menjamin pemenuhan kebutuhan perkembangan dengan cara memelihara dan merawat anggota keluarga yang sakit (Achar, 2010). Tugas keluarga di bidang kesehatan menurut Suprajitno (2004) yaitu mengenal gangguan kesehatan setiap anggota keluarga.

Pada perawatan anak hidrosefalus, tugas orangtua selanjutnya ialah memberikan perawatan kepada anak. Akan tetapi, merawat anak dengan hidrosefalus tidaklah mudah, seperti ungkapan Corridan (2014) mengatakan, "Saya dan istri tidak bisa mengubah kondisi anak saya yang sakit kronis. Membesarkan anak dengan kebutuhan khusus membutuhkan kerja ekstra, dibutuhkan waktu ekstra dan itu menyebabkan perhatian ekstra pada anak. Orangtua dengan anak berkebutuhan khusus membutuhkan waktu yang panjang untuk merawat anak." Begitu juga dalam penelitian ini, orangtua mengungkapkan berusaha dalam upaya merawat anak dengan hidrosefalus, orangtua merawat anak dengan penuh perhatian ekstra, serta merawat dengan penuh kasih sayang.

\section{Koping Orangtua yang Positif}

Tema koping orangtua yang positif ditemukan pada penelitian ini.

"Diterima ajalah dengan ikhlas. Ya memang tadinya saya emang nggak ikhlas ya Mbak bener-bener tidak ikhlas, terus lama kelamaan dengan suami saya bilang udah diikhlasin aja." (I6)

Kondisi anak yang sakit tentu saja memberikan dampak perubahan pada keluarga. Merawat anak yang sakit kronis seperti hidrosefalus tentu saja menimbulkan kecemasan dan stres terhadap orangtua. Mekanisme koping sangat diperlukan untuk dapat mengatasi dampak perubahan tersebut. Mekanisme koping orangtua merupakan respons terhadap upaya menerima kondisi anak yang sakit. Pada tema mekanisme koping orangtua, terdapat lima subtema, yaitu belajar ikhlas, bersabar, bersyukur, abaikan diri, dan pengharapan.

Penggunaan mekanisme koping pada orangtua yang memiliki anak dengan hidrosefalus sangat penting dan berguna untuk beradaptasi dengan kondisi anak yang mengalami gangguan perkembangan (Krstic, T. dan Oros, 2012). Pada penelitian ini, saat merawat anak hidrosefalus, ditemukan penggunaan respons positif, yaitu belajar ikhlas, bersabar, bersyukur dengan menerima apa yang telah Tuhan berikan, tidak peduli rasa sakit yang orangtua rasakan dengan mengabaikan diri dan pengharapan 
kesembuhan anak serta mendapat dukungan dari orang lain.

\section{Upaya Kesehatan}

Pada tema upaya kesehatan ini terdapat dua subtema, yaitu pelayanan kesehatan dan mandiri. Pada subtema pelayanan kesehatan terdapat sub-subtema, yaitu klinik, puksesmas, rumah sakit, dan lembaga swadaya masyarakat (LSM). Sementara itu, pada subtema mandiri terdapat sub-subtema merawat di rumah.

“... terus saya dirujuk ke rumah sakit, $N$ didiagnosis hidrosefalus di rumah sakit." (14)

Salah satu fungsi keluarga menurut Friedman (1998 dalam Andarmoyo, 2012) ialah memenuhi kebutuhan perawatan. Ketika anak sakit, orangtua akan mencari pelayanan kesehatan, membawa ke rumah sakit, pusat kesehatan, apoteker, dokter, bahkan ke pengobatan alternatif. Ketika keluarga memutuskan bahwa anggota keluarganya sakit, keluarga akan mengambil keputusan mengenai perawatan dan tindakan kesehatan yang tepat. Upaya kesehatan yang dipilih orangtua terhadap anak hidrosefalus bertujuan untuk meningkatkan kesehatan anak. Kondisi anak hidrosefalus sangat membutuhkan perawatan yang optimal (Suprajitno, 2004).

Berdasarkan asumsi peneliti, upaya kesehatan yang dilakukan orangtua menandakan bahwa anak memerlukan perawatan yang optimal. Tidak hanya menggunakan fasilitas kesehatan, orangtua juga mencari fasilitas kesehatan masyarakat untuk memberikan perawatan pada anak hidrosefalus. Perawatan optimal dapat dilakukan di institusi pelayanan kesehatan atau di rumah apabila keluarga telah memiliki kemampuan melakukan tindakan perawatan. Lembaga Swadaya Masyarakat (LSM) juga menjadiupayakesehatan orangtua. Orangtua mencari pihak-pihak yang dianggap mampu membantu perawatan anak, seperti yang diungkapkan informan dalam penelitian ini bahwa selama proses perawatan, informan mengalami kendala biaya yang minim. Akibat biaya minim ini, upaya kesehatan yang dilakukan orangtua adalah mencari Lembaga Swadaya Masyarakat.

\section{Perubahan Nilai}

Mengenai makna yang dirasakan orangtua yang memiliki anak dengan hidrosefalus, ditemukan tema perubahan nilai. Pada tema ini ditemukan dua subtema, yaitu spiritualitas dan perubahan sikap. Subtema spiritulitas terdapat sub-subtema mendekatkan diri pada Tuhan dan berdoa, subtema perubahan sikap terdapat subsubtema menjadi lebih baik, lebih bijak, dan keyakinan.

Nilai adalah suatu sistem ide, sikap, dan kepercayaan tentang suatu keseluruhan atau konsep yang secara sadar maupun tidak sadar terdapat dalam seluruh anggota keluarga. Nilai-nilai ini berfungsi sebagai pedoman dalam keluarga, yaitu membimbing perkembangan kehidupan keluarga (Parad dan Caplan, 1965 dalam Andarmoyo, 2012).

Sesuai dengan pengertian nilai Parad dan Caplan, dalam penelitian ini ditemukan perubahan nilai yang menghasilkan sikap menjadi lebih baik dan meningkatnya spiritualitas orangtua dengan adanya anak hidrosefalus. Orangtua mengungkapkan bahwa hidup mengalami perubahan dengan adanya anak hidrosefalus, yakni orangtua merasa menjadi lebih baik dalam menjalani hidupnya. Hal ini sejalan dengan penelitian Asyanti (2013) yang mengatakan dampak sakit kronis anak menjadikan orangtua dapat menguasai emosi dengan baik, orangtua bersikap baik dalam menghadapi setiap perubahan pada kondisi penyakit anak.

Menurut peneliti, perubahan nilai terjadi karena orangtua sudah dapat menerima kondisi anak dengan hidrosefalus, orangtua menganggap bahwa anak hidrosefalus 
adalah rejeki yang diberikan Tuhan sehingga harus dirawat dengan baik. Dengan hadirnya anak hidrosefalus, orangtua merasa menjadi semakin baik dalam kehidupannya.

"Saya lebih rajin sholat 5 waktu untuk kelancaran dan kesembuhan S." (I5)

“... hidup saya kayak dirubah gitu Iho walaupun anak saya kayak gini, tapi saya ngerasa jadi lebih baik lah dari yang kemaren-kemaren" (I2)

Adanya perubahan nilai yang dialami orangtua menggambarkan bagaimana penerimaan orangtua terhadap masalah serta pengambilan sikap yang tepat terhadap masalah anak hidrosefalus (Handayani, 208).

\section{SIMPULAN}

Berdasarkan hasil penelitian, penelitian ini memberikan gambaran dan pemahaman tentang pengalaman orangtua yang memiliki anak dengan hidrosefalus. Berdasarkan hasil analisis, diperoleh lima tema yang mengungkapkan pengalaman orangtua, antara lain proses berduka, proses perawatan, koping orangtua, upaya kesehatan, dan perubahan nilai. Disarankan kepada peneliti selanjutnya, perlu dilakukan penelitian yang lebih mendalam lagi tentang pengalaman orangtua yang memiliki anak dengan hidrosefalus, dengan berfokus pada perawatan anak yang belum melakukan operasi dan yang sudah operasi. Penelitian selanjutnya diharapkan tidak hanya menggunakan metode wawancara, tetapi bisa digabungkan dengan teknik lain.

\section{DAFTAR PUSTAKA}

Achjar, K.A. (2010). Asuhan Keperawatan Keluarga. Jakarta: Sagung Seto.

Afiyanti, Y. (2008). Validitas Dan Reliabilitas Dalam Penelitian Kualitatif. Depok: Uljki.

Andarmoyo, S. (2012). Keperawatan Keluarga; Konsep Teori, Proses dan Praktik Keperawatan. Yogyakarta: Graha
Ilmu.

Asyanti, S. (2013). "Dinamika Permasalahan Pada Orang Tua yang Meiliki Anak Dengan Penyakit Kronis dan Tantangan Dalam Mengantarkan Anak Menjadi Pribadi Yang Lebih Sehat dan Berkarakter Tanguh". Prosiding Seminar Nasional 2013, 214-224.

Ball, J., Bindler, R. C., and Cowen, K. J. (2012). Principles of Pediatric Nursing. USA: Pearson Education.

Chapman, A. (2013). Elisabeth Kubler-RossFive Stages of Grief. Retrieved from http://www.businessballs.com.

Community, T.H. (2013). Who Develops Hydrocephalus? Retrieved from Hydrocephalus Association Website: http://www.hydroassoc.org.

Corridan, K. (2014). What Is Really Means To Have A Child With Special Needs. Retrieved from Parents: http://www. parents.com. Diakses 12 September 2015.

Depkes, D.K. (2014). Kondisi Pencapaian Program Kesehatan Anak Indonesia. Jakarta: Pusat Data dan Informasi Kementerian Kesehatan RI.

Edikta. (2011). Hidrosefalus di RSU Dr. Soedarso Pontianak dalam Masa 1 Januari 2008-31 Desember 2009. Pontianak: Universitas Tanjungpura.

Handayani, M. D. (2008). Dampak Psikologis Ibu yang Memiliki Anak Hydrocephalus. Semarang: Universitas Katolik Soegijapranata.

Koesoemo, R.F. (2010). "Proses Berduka dan Beban yang Dialami Keluarga dalam Merawat Anak Dengan Autisme". Ners Journal, 182-191.

Krstic, T. and M.O. (2012). Coping with Stress and Adaptation in Mother of Children With Cerebral Palsy. NCBI.

Maliawan, S.D.(2008). "PerbandinganTekhnik Endoscopic Third Ventriculostomy (ETV) dengan Ventriculoperitoneal Shunting 
(VPS) pada Hidrosefalus Obstruksi". Marijani, L. (2003). Bunga Rampai Seputar Autisme dan Permasalahannya. Jakarta: Putrakembara Foundation.

Mutaqqin, A. (2011). Pengantar Asuhan Keperawatan dengan Gangguan Sistem Persarafan. Jakarta: Salemba Medika.

Organization, W.H. (2012). Communitybased Support for Children with Spina Bifida and Hydrocephalus in Uganda. Retrieved from World Health Organization Website: http://www.who. int
Polit, D.F. and Beck, C.T. (2012). Essentials of Nursing Research. Philadelphia: Lippincott Williams \& Wilkins.

Puri, B. K., Laking, P. J., and Treasaden, I. H. (2011). Buku Ajar Psikiatri. Jakarta: EGC.

Santun, S. dan Agus, D.C. (2008). Penuntun Praktis Asuhan Keperawatan. Jakarta: Trans Info Media.

Suprajitno. (2004). Asuhan Keperawatan Keluarga; Aplikasi dalam Praktik. Jakarta: EGC.

Wasis. (2008). Pedoman Riset Praktis untuk Profesi Perawat. Jakarta: EGC. 